\section{Mesenchymal stromal/stem cells: historical perspective and ongoing challenges}

\section{Células-tronco estromais mesenquimais: perspectiva histórica e desafios contínuos}

\author{
Maria Isabel Doria Rossi',2* (D) \& Danielle Cabral Bonfim¹ (D) \\ 'PhD. Instituto de Ciências Biomédicas, Universidade Federal do Rio de Janeiro - UFRJ, Rio de Janeiro, RJ, Brasil \\ ${ }^{2}$ PhD. Hospital Clementino Fraga Filho, Universidade Federal do Rio de Janeiro - UFRJ, Rio de Janeiro, RJ, Brasil
}

\begin{abstract}
The potential of stem cell-based therapy was accompanied by high expectations and led, consequently, to an increase in clinical translational investments. Mesenchymal stem/stromal cells (MSCs) became the cell-based product most experimentally studied worldwide. However, uncertainties about the mechanisms and the in vivo identity of MSC simpose concerns about their large-scale use in regenerative medicine. This review comprises a historical summary on MSC, a critical discussion about their identity and function, and the ongoing challenges for their use in therapy and tissue bioengineering.
\end{abstract}

Keywords: stem cells, mesenchymal stem/stromal cells, cell therapy.

\section{Resumo}

O potencial das células-tronco adultas para terapias celulares é cercado de grande expectativa e, consequentemente, levou a um aumento nos investimentos na clínica translacional. As células-tronco mesenquimais, também denominadas células mesenquimais do estroma (MSCs, Mesenchymal Stem/Stromal Cells) se tornaram o produto celular mais estudado experimentalmente em todo o mundo. Entretanto, incertezas a respeito das propriedades e da identidade in vivo das MSCs levantam questões sobre seu uso extenso em medicina regenerativa. Esta revisão compreende um breve histórico sobre as MSCs, uma análise crítica a respeito de sua identidade e função e os permanentes desafios para seu uso terapêutico em bioengenheria.

Palavras-chave: células-tronco, células tronco mesenquimais, células tronco mesenquimais/estromais, terapia celular.
How to cite: Rossi, M. I. D., \& Bonfim, D. C. (2020). Mesenchymal stromal/stem cells: historical perspective and ongoing challenges. Brazilian Journal of Veterinary Medicine, 42, e112020. doi: 10.29374/2527-2179.bjvm112020

Financial support: CAPES, CNPq, FAPERJ

Conflict of interests: No conflict of interests declared concerning the publication of this article.

Received: May 01, 2020.

Accepted: May 01, 2020.

The study was carried out at Instituto de Ciências Biomédicas, Universidade Federal do Rio de Janeiro - UFRJ, Rio de Janeiro, RJ, Brasil.

\section{*Correspondence}

Maria Isabel Doria Rossi

Hospital Universitário Clementino Fraga Filho, Universidade Federal do Rio de Janeiro - UFRJ R. Prof. Rodolpho Paulo Rocco, 255, sala 4A9,

Cidade Universitária, Ilha do Fundão CEP 21941-913 - Rio de Janeiro (RJ), Brasil

E-mail: idrossi@hucff.ufrj.br
Copyright Rossi et al. This is an Open Access article distributed under the terms of the Creative Commons Attribution Non-Commercial License which permits unrestricted non-commercial use, distribution, and reproduction in any medium provided the original work is properly cited. 


\section{Introduction}

Adult stem cells were defined in the XX century as a cell population able to self-renew and to give rise to specific tissue differentiated cells, replenishing lost cells. Currently, it is well agreed that almost all adult tissues contain a stem cell population that reside in specific microenvironments (the stem cell niche) and give rise to downstream committed progenitors that generate terminally differentiated cells (Clevers, 2015; Ferraro et al., 2010; Morrison \& Spradling, 2008; Post \& Clevers, 2019; Quesenberry \& Goldberg, 2017; Slack, 2018). The concept of a stem cell-based unidirectional hierarchical organization of tissues has its roots in studies about the reconstitution of the hematopoietic tissue. The attempt to rescue patients from the lethal effects of ionizing radiation after the second world war and from chemotherapy led to the first bone marrow transplantation (Thomas et al.,1957). The success impelled the research on bone marrow cell biology that experienced a great impact by the technological advances in the '80s, with the invention of Fluorescence Activated Cell Sorter (FACS) (Herzenberg et al., 2002), since this new technology allowed the phenotypic characterization and isolation of hematopoietic stem cells (HSCs) from murine and human bone marrow (Spangrude et al., 1988; Sutherland et al., 1989). In parallel, a population of clonogenic multipotent stromal cell, named later as mesenchymal stem cell (MSC) (Caplan, 1991), was identified in the bone marrow (Andrzejewska et al., 2019; Bianco, 2014, 2015; Friedenstein et al., 1966). The following decades witnessed a tremendous increase in our knowledge on stem cell biology driven by the potential to improve healthcare by cellular therapy for regenerative medicine.

Recent data on the biological properties of stem cells derived from a variety of adult tissues are challenging the idea that all adult stem cells comprise a rare and quiescent population. Stem cell division seems to be driven by tissue-specific demands under physiological or pathological conditions, which means that in some tissues, as in the gut, stem cells are neither rare nor quiescent. Moreover, some plasticity of the unidirectional differentiation of progenitors was observed (Clevers, 2015; Klein \& Simons, 2011; Post \& Clevers, 2019; Quesenberry \& Goldberg, 2017; Slack, 2018). So, what makes a cell a stem cell? A broad definition of stem cells as cells capable to replenish lost tissues, whose properties are controlled by their microenvironment has been proposed, based on data from murine models (Guiu et al., 2019; Post \& Clevers, 2019; Quesenberry \& Goldberg, 2017). Further investigations are needed in order to confirm whether this statement can be widely applied. However, the pivotal role of the microenvironment in stem cell fate decisions is of great interest, since it may impact the outcomes of cell therapy, even leading to undesired consequences, as already observed in MSC-based cell therapy (Hoogduijn \& Lombardo, 2019; Packer, 2018). This review encompasses a brief historical perspective on the so-called MSC, a critical discussion about their identity and function, and the challenges for their use in therapy and tissue bioengineering.

\section{Origin of the terms "stem cell" and "mesenchymal stem/stromal cells"}

The term stammzelle (stem cell) was introduced in the XIX century by the German scientist Ernst Haeckel to designate the ancestor unicellular organism that he believed was the origin of all multicellular organisms. Few years later, Haeckel proposed that the fertilized egg should also be called stammzelle. The term stem cell, as we presently understand, i.e, designating a cell population capable of self-renewal and to give rise to specific tissue differentiated cells, first appeared in studies regarding the regeneration of the hematopoietic tissue. Pappenheim, a German scientist, was the first to mention the term stammzelle in his manuscripts about the hematopoietic tissue. However, it was Alexander Maximow, a Rusian-American scientist, who was accredited for coining the term stem cell for the cell population that, as he postulated, gives rise to all hematopoietic lineages due to the local influence of the bone marrow stroma (Konstantinov, 2000; Ramalho-Santos \& Willenbring, 2007; Slack, 2018). It is interesting to note that with this statement, Maximow also anticipated the idea of the stem cell niche, that is, the specialized microenvironment that determine the stem cell activity and fate, which was proposed many years later by Schofield (1978).

It was by the 1960 decade, after the first bone marrow transplant in human patients, that the field of stem cell biology in the hematopoietic system truly flourished, with experimental data provided by Drs. James E. Till and Ernest McCulloch definitely demonstrating that all blood cells 
were derived from a multipotent progenitor. Also, the authors developed an in vivo clonogenic assay, the spleen colony-forming unit (CFU-S), that allowed them to estimate the number of multipotent hematopoietic progenitors in the bone marrow (Till \& McCulloch, 1961). In the '80s, as mentioned above, HSCs from murine and human bone marrow were extensively characterized (Spangrude et al., 1988; Sutherland et al., 1989).

The discovery that the bone marrow had a second class of stem cell came because of the interest of scientists in the relationship between bone and blood production. The first evidence that bone marrow contained cells able to form bone tissue and a hematopoietic supportive stroma were provided by experiments showing that ectopic ossicles with reticular stroma was formed after subcutaneous transplantation of bone marrow fragments devoid of bone. In a series of studies, it was shown that the cells able to form the heterotopic ossicles resided within a clonogenic population of the bone marrow stroma, the colony-forming units - fibroblast (CFU-F) (Andrzejewska et al., 2019; Bianco, 2014, 2015; Friedenstein et al., 1966; Castro-Malaspina et al., 1980; Luria et al., 1971; Bianco \& Robey, 2015; Tavassoli \& Crosby, 1968). CFU-Fs are identified by plating bone marrow cell suspensions at low density $\left(100\right.$ cells $\left./ \mathrm{cm}^{2}\right)$. After few days, adherent cells proliferate, forming colonies of cells with fibroblast-like morphology (Figure 1). Analysis of the differential potential of individual colonies revealed that some, but not all, of these CFU-Fs were multipotent, i.e, able to generate both bone and the marrow stroma. Others were only able to form bone or had no differentiation potential (Owen, 1988; Owen \& Friedenstein, 1988). Altogether, these data suggested that the clonogenic bone marrow stromal cell fraction is a mixture of cell types organized hierarchically, with a multipotent stem cell at the top, from which a spectrum of committed progenitors branch in the path to the mature cell types that compose the bone and bone marrow tissues.

A

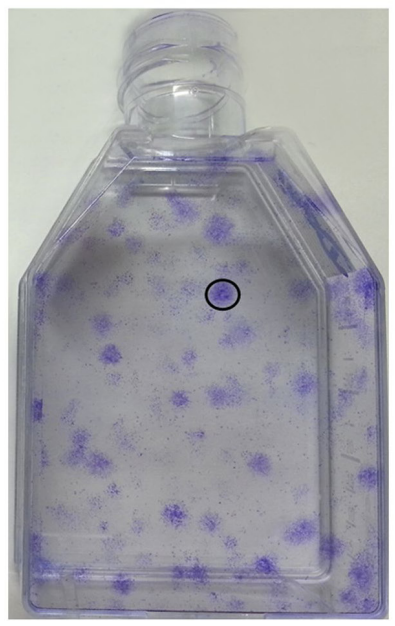

B

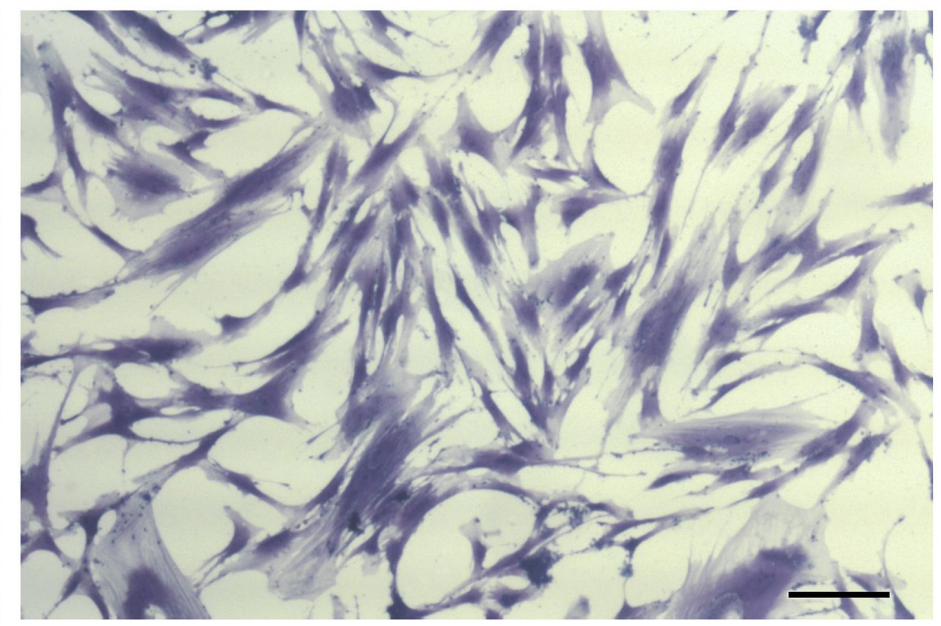

Figure 1. Fibroblast colony-forming unit (CFU-F). Bone marrow cells were plated at low density $\left(100 \mathrm{cells} / \mathrm{cm}^{2}\right)$ and maintained for 3 days in culture. Non-adherent cells were removed and the cultures were maintained for up to 10 days. The colonies were fixed and stained with a solution of $1 \%$ crystal violet. (A) Macroscopic aspect of the colonies. The circle indicates one individualized colony; (B) Microscopic aspect of the cells in the colonies. Bar $=50 \mu \mathrm{m}$.

The term "mesenchymal stem cell" (MSC) was coined by Dr. Arnold Caplan, in 1991, who hypothesized that the clonogenic multipotent bone marrow stem cell was the adult counterpart of an embryonic mesenchymal stem cell that originates cartilage, bone, tendon, ligament, marrow stroma, fat, dermis, muscle, and connective tissue during development. Under the light of this concept, adult MSCs could then be viewed as a promising therapeutic agent for the repair of several tissues, besides bone (Caplan, 1991). Although this paper was the first to propose the therapeutic use of MSC, this idea only gained popularity after a study by Pittenger and colleagues was published, showing that under specific culture conditions human bone marrow-derived MSCs can be induced to differentiate toward the osteogenic, adipogenic and chondrogenic lineages 
(Pittenger et al., 1999). Despite no stem cell properties were shown, a great interest was raised by the clinical potential of the so-called MSCs, as predicted by Dr. Caplan. Therefore, a company proposing to improve healthcare through cellular therapy for regenerative medicine was founded on the "discovery" of MSCs, as stated in its portfolio. Actually, the shift in science and research development (R\&D) policy toward the paradigm of "translational" science was started in the '80s. The emergent role of the contract research organization (CRO) in the commercialization of scientific research focused in innovation of clinical treatment, among other areas, impelled the rise of private companies with the aim to develop new therapeutic approaches (Mirowski \& Van Horn, 2005). This scientific policy boosted the field of stem cell for clinical application in cellular therapy and throwed the scientific community into a jungle of amazing expanding literature.

\section{Confusions and misconceptions under the MSC umbrella}

In accordance with the shift towards translational science, the dawn of the XXI century witnessed a tremendous excitement over the possible use of the so-called MSCs in regenerative medicine. This enthusiasm led to a dramatic increase in the number of published articles (Figure 2) that echoed the number of research groups interested in the field. Following the rationale that MSCs were a reminiscent of an embryonic mesenchymal stem cell, scientists started a search for similar cell populations within several organs. Indeed, cells with the characteristics of bone marrow-derived MSCs, that is, plastic adherent fibroblast-like cells that are able to differentiate in vitro towards osteogenic, adipogenic, and chondrogenic lineages were isolated from a variety of human and rodent tissues: skeletal muscle (Williams et al., 1999); cord blood (Erices et al., 2000); dental pulp (Gronthos et al., 2000); adipose tissue (Zuk et al., 2001); synovial membranes (Bari et al., 2001); peripheral blood (Kuznetsov et al., 2001); fetal tissues (Campagnoli et al., 2001); and amniotic fluid (In't Anker et al., 2003). Subsequently, it was shown by the group of Dr. Nardi that virtually all post-natal organs and tissues harbor cells with the characteristics of MSCs (Silva Meirelles et al., 2006), generating a positive feedback loop of enthusiasm and widening the proposals of clinical applications.

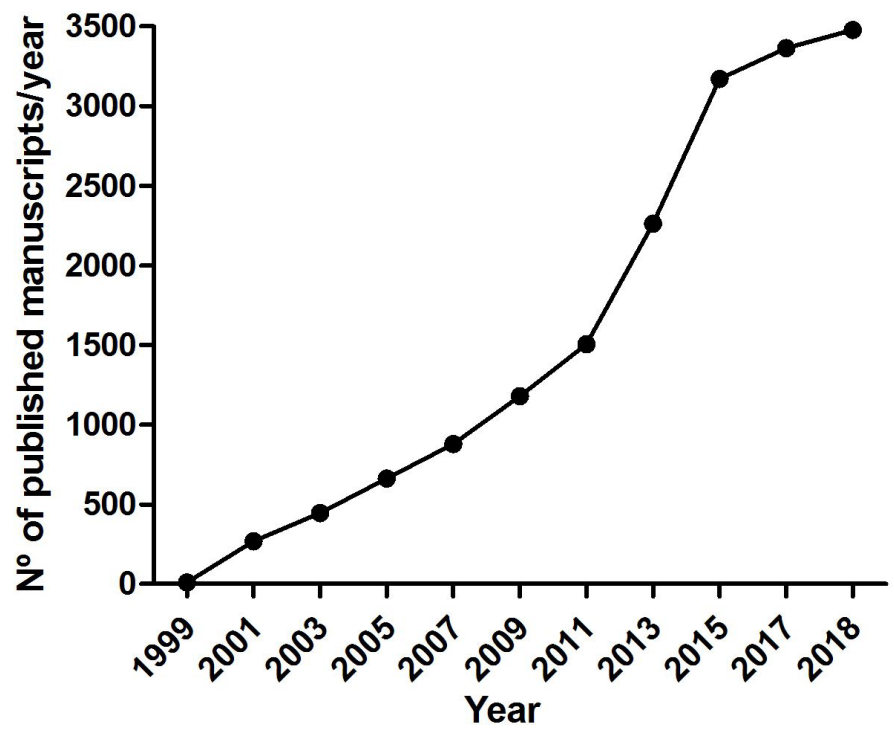

Figure 2. Number of scientific manuscripts on mesenchymal stem/stromal cells published over time. Timeline of published scientific articles about MSCs. The research was done in PubMed database using the terms "mesenchymal stem cell" OR "mesenchymal stromal cell".

This scenario was further strengthened by numerous coincidently published manuscripts suggesting that a variety of adult stem cells were able to differentiate across embryonic germ layers (Krause et al., 2001; Lagasse et al., 2001; Wagers \& Weissman, 2004), a classically recognized restricted attribute of pluripotent stem cells. Although some "plasticity" (Chart 1) of tissue-specific adult stem cells does exist, definitive evidence of MSC pluripotency have never been provided 
Chart 1. Glossary.

\begin{tabular}{|l|l|l|}
\hline \multicolumn{1}{|c|}{ Term } & \multicolumn{1}{|c|}{ Definition } & \multicolumn{1}{c|}{ Examples } \\
\hline Plasticity & $\begin{array}{l}\text { The phenomenon by which a } \\
\text { differentiated cell changes its phenotype } \\
\text { and functional properties due to } \\
\text { microenviromental influence }\end{array}$ & $\begin{array}{l}\text { Chondrocytes can revert into } \\
\text { fibroblast-like cells. A subpopulation of } \\
\text { gastric chief cells can revert to a gastric } \\
\text { stem cell phenotype }\end{array}$ \\
\hline Pluripotency & $\begin{array}{l}\text { The capacity to differentiate into } \\
\text { all intraembryonic tissues, that is, } \\
\text { endoderm, ectoderm or mesoderm- } \\
\text { derived lineage cells. }\end{array}$ & $\begin{array}{l}\text { Embryonic stem cells (ES) derived from } \\
\text { the inner mass of the blastocyst, and } \\
\text { genetically reprogrammed iPS cells are } \\
\text { the only truly pluripotent cells. }\end{array}$ \\
\hline Multipotentiality & $\begin{array}{l}\text { The capacity to differentiate and generate } \\
\text { all cellular lineages of a specific tissue. }\end{array}$ & $\begin{array}{l}\text { Hematopoietic stem cells (HSCs) that } \\
\text { generate all blood cells. } \\
\text { Mesenchymal stem cells (MSCs) } \\
\text { differentiate into cells from the tissue } \\
\text { they are derived. Bone marrow MSCs } \\
\text { form bone, cartilage, reticular stromal } \\
\text { cells, and adipocytes. }\end{array}$ \\
\hline
\end{tabular}

(Bianco et al., 2013). What was found was that MSCs, when transplanted in vivo, with no chemical inducers, exclusively formed mature cells of their tissue of origin. Specifically, in the case of bone marrow MSCs, the only tissues formed were bone, cartilage, marrow adipocytes and mielosupportive stroma, as already shown by the seminal studies of the field. As the tissues formed in vivo, from all tissue-specific MSCs, were always of the same embryonic germ layer, it became clear that these cells are, at most, multipotent. Currently, there is no doubt that blastocyst-derived embryonic stem cells (ES cells) and reprogrammed iPS cells (induced pluripotent stem cells) are the only truly pluripotent stem cells (Bonfanti et al., 2012; Camargo et al., 2004; Theise, 2010).

While some were still mourning the unquestionable restricted MSC differentiation potential, soon a new wave of enthusiasm hit the field, with evidence pointing to an otherwise MSC capacity to stimulate tissue repair by the promotion of angiogenesis and the modulation of inflammation (Castelo-Branco et al., 2012; Chen et al., 2015; Fitzsimmons et al., 2018; Silva Meirelles et al., 2009; Le Blanc et al., 2004; Mastrolia et al., 2019; Menezes et al., 2014; Prockop \& Youn Oh, 2012; Spees et al., 2016; Weiss \& Dahlke, 2019). Fueled, the field kept growing and several distinct cell types, isolated from different sources, were all gathered under the same inappropriate nomenclature: mesenchymal stem cells. Amidst all different MSC tissue sources, methods of isolation, expansion, and characterization that started showing up, the International Society for Cellular Therapy (ISCT) then tried to organize the mess, publishing two position statements. The first proposed a consensual nomenclature. Regardless the tissue of origin, multipotent fibroblast-like cells should then be termed mesenchymal stromal cells, unless stem cell properties, such as self-renewal, were indeed confirmed (Horwitz et al., 2005). However, this consensual nomenclature still perpetuates the confusion, since it mixes different cell types under a same name. Furthermore, the acronym MSCs could still be used for mesenchymal stem cells as well as for multipotent mesenchymal stromal cells. Lastly, because by this time, the nomenclature "mesenchymal stem cell" was already so loaded with expectations and attention, both inside the academia - including the funding sources - and by the general public, it became difficult to convince scientists to rename all the tissue-specific cells with more appropriate, but less catching, terms; and unfortunately it remains until today.

The second statement established minimal criteria to define a given cell population as MSCs: (i) the cells should be plastic-adherent in standard culture conditions; (ii) should have the potential to differentiate into osteoblasts, chondrocytes, and adipocytes in vitro; and (iii) should express the surface antigens CD105, CD73, and CD90 in the absence of CD45, CD34, CD14 or CD11b, HLA-DR, CD79a or CD19 (Dominici et al., 2006). Other surface antigens were also suggested in order to phenotypically characterize human MSCs, such as CD13, CD10, CD29, CD44, CD146, CD271, Stro-1, SSEA-4 (stage-specific embryonic antigen-4), and MSCA-1 (mesenchymal stem cell antigen-1) (Fitzsimmons et al., 2018; Lin et al., 2013; Lv et al., 2014; Quirici et al., 2002; Sacchetti et al., 2007; 
Simmons \& Torok-Storb, 1991). In this case, the point is that none of the surface antigens proposed are specific. On the contrary, they are broadly expressed by several mature cell types, such as connective tissue fibroblasts. Moreover, the expression of the proposed CDs is variable in MSCs from different sources and may be modulated by in vitro expansion (Bianco et al., 2013; Lv et al., 2014; Robey, 2017; Tormin et al., 2011). Therefore, this immunophenotype is solely useful to characterize plastic adherent fibroblast-like cells. Regarding in vitro differentiation assays, it is known that these protocols are prone to artifacts and even a positive in vitro differentiation for the three lineages - osteogenic, adipogenic, and chondrogenic - does not guarantee the formation of those tissues when the same cell population is transplanted in vivo. So, again, this kind of information is not predictive of the cell biological properties in vivo.

Isolation and expansion of MSC-like cells from other mammals, mostly from companion animals (dogs and cats) but also from horses, pigs, and goats, rapidly followed the reports on humans and rodents. Their phenotype was based on human markers since no species-specific antibodies were available (Devireddy et al., 2017; Fortier \& Travis, 2011; Rozemüller et al., 2010). Application of MSC-based products for cell therapy in veterinary medicine experienced an exponential expansion following the same trend observed in the area of regenerative medicine for human patients.

\section{MSCs identity in vivo: what are we talking about?}

The in vivo identity and tissue localization of the cell population named MSCs is still debatable since they were defined by their in vitro properties. Isolation of cells that behave as MSCs (MSC-like cells) from so many different organs led to the hypothesis that they should reside in association with blood vessel walls (Silva Meirelles et al., 2006, 2008), as proposed earlier for bone marrow clonogenic stromal cells and for myogenic progenitors (Bianco \& Cossu, 1999). The first experimental evidence that bone marrow clonogenic multipotent stromal cells comprise a perivascular population was provided by Dr. Bianco and colleagues. The authors observed that the human multipotent bone marrow CFU-Fs are found within a perisinusoidal reticular cell population expressing CD146. Moreover, as in seminal studies of the field, these cells were able to form bone and marrow stroma after subcutaneously transplantation in mice. In the heterotypic grafts, the cells were observed at the abluminal face of sinusoids and could be isolated and secondarily expanded, suggesting that they possessed self-renewal capacity. The authors named these cells as skeletal stem cells (SSCs), since they were able to form bone, cartilage, and marrow stroma, but no other mesodermal-derived tissues (Sacchetti et al., 2007; Bianco \& Robey, 2015). However, as pointed out above, at this point the term MSC was already widely used and the nomenclature "skeletal stem cells" for bone marrow stromal stem cells was not extensively adopted.

In the footsteps of these findings, several studies aiming to correlate MSCs-like cells with perivascular cell populations in a variety of tissues were published. Multipotent CD146 ${ }^{+}$stromal cells were identified in human adipose tissue as perivascular cells juxtaposed to endothelial cells as pericytes (Crisan et al., 2008). MSC-like cells expressing CD34 were also isolated from the adventitia of human blood vessels, the outermost tunica of arteries and veins (Billaud et al., 2017; Corselli et al., 2012; Hoshino et al., 2008). Isolated blood vessel mural cells were shown to contribute to tissue repair after transplant (Chen et al., 2015; Dellavalle et al., 2007) and lineage tracing assays designed to investigate the relationship between MSC and mural blood vessel cells showed that MSCs-like cells arise from perivascular cell populations (Feng et al., 2011; Göritz et al., 2011; Tang et al., 2008). All together, these studies straightened the idea that all MSC would be perivascular cells, residing in association with the microcirculation, as pericytes, or within the walls of arteries and veins, and would display comparable biological properties, regardless the tissue of origin (Caplan, 2008; Chen et al., 2013; Murray \& Péault, 2015). This impelled the use of this cells as a source for cell therapy since no tissue-specific MSC isolation would be necessary, bypassing the inherent difficulties of large-scale expansion of cells from tissues where their frequency is low, as muscle and bone marrow. Again, this enthusiasm was constructed over a misconception that relied on the assumption that all perivascular stromal cells that behave as MSCs originated from a common embryonic mesenchymal stem cell as a result of a "mesengenic process", as proposed by Caplan (Caplan, 1991). Nevertheless, the mesengenic concept clashes with classical concepts 
of embryonic development and concrete evidence of this event have never been provided. On the contrary, what became evident is that, in fact, MSCs from different tissues were not equal, but rather, tissue-specific progenitors, with distinct differentiation potentials. Analysis of the potential of human CD146 ${ }^{+}$perivascular cells isolated from bone marrow, periosteum, skeletal muscle, cord blood, and adipose tissue revealed wide differences in their biological features and transcriptomic signatures (Sacchetti et al., 2016). In agreement, distinguishable single cell RNA sequences and transcriptomic signatures of in vitro expanded MSCs derived from different murine (Ho et al., 2018) and human (Cho et al., 2017; Roson-Burgo et al., 2016) tissues were shown.

To add more complexity to the field, perivascular cells form a heterogeneous population in terms of phenotype, ontogeny and biological properties. The tunica adventitia is a layer of loose connective tissue containing fibroblasts, adipocytes, small blood vessels (vasa vasorum) and nerve fibers. Recently, another stromal cell population, called telocytes, was shown to encircle externally blood vessels and form an interstitial mesh by interconnecting their long cytoplasmic projections (telepods). Although the function of telocytes in vivo still needs to be unraveled, they seem to share some biological properties with MSCs, as the regulation of immune response (DíazFlores et al., 2014; Cretoiu et al., 2017; Kondo \& Kaestner, 2019; Vannucchi \& Faussone-Pellegrini, 2016; Wang et al., 2016) and, so, the relationship between telocytes and MSCs is under screening. However, data available on gene expression profile of in vitro expanded pulmonary telocytes, fibroblast and MSCs cell lines (Cretoiu et al., 2017; Wang et al., 2016; Zheng et al., 2013) suggest that these cells comprise distinct populations.

Regarding pericytes, these cells form a heterogenous population of mural cells embedded within the basal membrane of small blood vessels, which coverage is fundamental for vascular stability (Armulik et al., 2011; Díaz-Flores et al., 2009). In a tissue- dependent manner, pericytes are derived from embryonic mesenchymal and neural crest cells (Birbrair, 2018; Birbrair et al., 2015; Prazeres et al., 2017; Yamazaki \& Mukouyama, 2018). Cells from the neural crest migrate extensively during development and contribute to a plethora of cranial and trunk neural and non-neural cells (Dupin et al., 2018; Hay, 2005). Interesting, it was shown that neural crest cells supply a transient wave of MSCs that migrate to the bone marrow during development (Takashima et al., 2007), suggesting a dual origin for MSCs - mesoderm and neural crest - a hypothesis that has been strengthened by iPS-derived MSCs assays (Chijimatsu et al., 2017; Eto et al., 2018; Fitzsimmons et al., 2018). However, although, MSC-like cells were obtained by inducing differentiation of iPS into mesoderm-like cells and neuroepithelium-like cells, differences in the biological properties related to the cell origin were observed (Eto et al., 2018), in accordance with previous study that showed that neural crest- derived bone marrow MSCs constitute a functionally distinct population that differ from mesoderm-derived MSCs with osteochondral potential in adults (Isern et al., 2014).

Finally, the relationship between MSCs and blood vessel mural cells was recently challenged by different strategies of lineage tracing. Guimarães-Camboa and colleagues showed that pericytes and smooth muscle vascular cells, although multipotent in vitro, do not behave as MSCs in vivo (Guimarães-Camboa et al., 2017). These findings contrast with previous studies also using lineage tracing assays and rise important questions. First, lineage tracing assays (Figure 3) rely on the specificity of the genetic marker selected (Kretzschmar \& Watt, 2012; Li et al., 2018; Nagy, 2000). Secondly, the differentiation potential of isolated cells may be influenced by the ex vivo manipulation and mechanical stimuli (Alimandi et al., 2019; Engler et al., 2006; Freeman et al., 2015; Liu et al., 2017, 2019; McBeath et al., 2004), which should be carefully considered whenever in vitro expansion of cells are needed for cell therapy. Nevertheless, not all mural blood vessel cells seem to be able to behave as MSCs and this property may depend on the developmental stage and the organ of origin, that is, the embryonic origin of the cells and their post-natal microenvironment may impose their biological properties.

In conclusion, MSCs were characterized in vitro and their in vivo identity still needs further investigations. New scientific tools, as single cell RNA sequencing, new generation of flow cytometer and confocal microscopes, would improve our current knowledge about the heterogeneity of the stromal cell populations. 
A

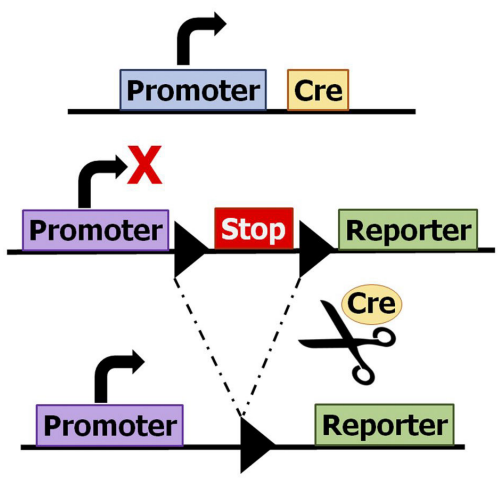

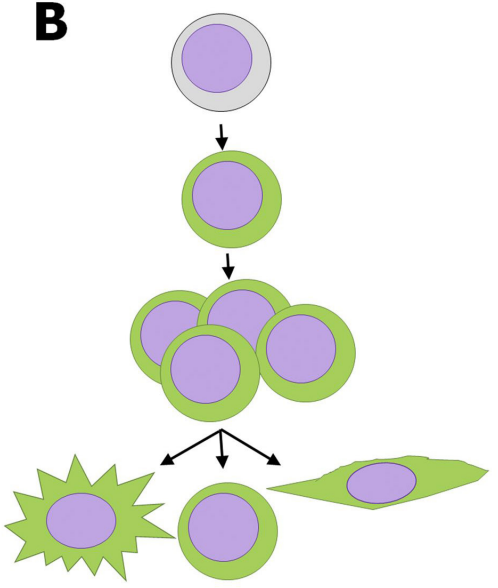

Figure 3. Lineage tracing assay. (A) The Cre/loxP recombinase system. The Cre-recombinase gene of the P1 bacteriophage is placed under the control of a promoter of a gene specifically expressed by the cell population of interest. Cre recombinase efficiently catalyzes recombination of DNA segments between two of its recognition sites, called loxP. The loxP sites flank a stop codon introduced between the promoter and the reporter gene. Activation of the cell population specific gene promoter leads to the expression of Cre recombinase. The Cre-recombinase mediates the deletion of the loxP site-flanked stop codon between the promoter and the reporter gene (GFP, green fluorescent protein in the example). Since the promoter is constitutively active, it induces the permanent expression of the reporter gene. Consequently, the progeny of the positive labeled cell will also express the reporter gene; (B) An undifferentiated stem cell activates its differentiation program. Expression of the specific target gene induces Cre-recombinase expression and subsequently the expression of the product of the reporter gene (GFP). The cell and its progeny are permanently GFP+ (in green).

\section{The hope of MSC-based products for regenerative medicine: are we sure about the safety and efficacy?}

The potential of stem cell-based therapy has led to high expectations and consequently to an increase in clinical translational investments. The main concerns are the marketing and sale of stem cell products and their application in unproven therapies with pitiful outcomes that can harm patients (Berger et al., 2014; Fung et al., 2017). Recognizing these concerns, the ISCT published a position document intended to inform professionals and patients on unproven cell-based therapies (Dominici et al., 2015) and the International Society for Stem Cell Research (ISSCR) updated it in 2016 (International Society for Stem Cell Research, 2016) the Guidelines for the Conduct of Human Embryonic Stem Cell Research (International Society for Stem Cell Research, 2006) and the Guidelines on the Clinical Translation of Stem Cells (International Society for Stem Cell Research, 2008). The 2016 Guidelines for Stem Cell Research and Clinical Translation aim to "[...] promote an efficient, appropriate and sustainable research enterprise for stem cell research and medical interventions" and establish standards for clinical research conducts (International Society for Stem Cell Research, 2016, p. 20; Recommendation 3.3.2). Among other recommendations, the guideline points out that: (i) the launch of clinical trials should be supported by scientific evidence; (ii) risks should be identified and minimized; and (iii) stem cell-based therapies should be safe and effective and must aim to be superior to an existing therapy.

Since the first report on a phase I trial to determine the feasibility and safety of intravenous infusion of in vitro expanded bone marrow stromal cells (Lazarus et al., 1995), adult MSCs became the cell-based product most experimentally studied worldwide. Bone marrow and adipose tissue are the major sources of MSCs for cell-based therapies, although few studies have compared their effect side by side (Abbas et al., 2006; Castelo-Branco et al., 2012; Kern et al., 2006; Menezes et al., 2014). Their allegedly capacity to improve tissue repair, along with the possibility to obtain these cells from different sources, led to a great expectation on the efficacy of MSCs products for regenerative medicine. Initially, MSCs-based therapies were focused on their multilineage differentiation capacity. More specifically, autologous or allogeneic bone marrow-derived MSCs were viewed as a promising cell product to improve the repair of bone tissues, due to their osteogenic potential (Ankrum \& Karp, 2010; Ferreira et al., 2012). The focus later changed toward the potential of MSCs to improve tissue repair by paracrine signaling, since it was shown that MSCs derived from different sources secrete an array of soluble factors (cytokines, chemokines and 
growth factors) and extracellular matrix molecules that promote angiogenesis, inhibit apoptosis, stimulate cell proliferation, and modulate the inflammatory and immune reactions (Ankrum \& Karp, 2010; Castelo-Branco et al., 2012; Silva Meirelles et al., 2009; Hoogduijn \& Lombardo, 2019; Menezes et al., 2014; Mastrolia et al., 2019). Influenced by the enthusiasm about the therapeutic potential of MSCs due to paracrine effects, Dr. Caplan proposed the provocative term "Medicinal Stimulating Cells" that would skip the controversy about the term "Mesenchymal Stem Cells" but allow to keep the acronym MSC (Caplan, 2010). The term "Medicinal Stimulating Cell" foretells that these cells would have beneficial effects regardless of their origin and the pathological condition, which is not the case, as discussed below. More recently, a new mechanism called attention: the therapeutic potential of MSCs-derived extracellular vesicles (EVs), heterogeneous nano-sized membrane enveloped cell-derived vesicles that are thought to be involved in cell signaling via transfer of their cargo (French et al., 2017; Gimona et al., 2017; Katsuda \& Ochiya, 2015; Latifkar et al., 2019; Mastrolia et al., 2019; Phinney \& Pittenger, 2017; Willis et al., 2017).

To achieve the needs for clinical application of MSCs, a variety of tools designed to improve isolation, differentiation, and in vitro expansion was developed (Mastrolia et al., 2019; Dias et al. 2019). We are now able to expand MSCs from different sources in order to get sufficient number of cells to use in different clinical protocols, although the mechanisms of action for the distinct clinical conditions are still largely unknown (Ankrum \& Karp, 2010, Mastrolia et al., 2019). Consequently, disappointing outcomes or even adverse effects, as induction of cardiac fibrosis in diabetic patients (Hoogduijn \& Lombardo, 2019; Packer, 2018), should not be completely unexpected. Discrepancy between the positive results of MSCs application in a diversity of experimental models and the disappointing outcomes in human clinical trials raised concerns about the use of MSCs for cellular therapy. Cell variability and absence of standardized protocols to confirm product quality, lack of knowledge about the mechanisms of action and the fate of MSCs in vivo, and insufficient data from clinical trials challenge the capacity to demonstrate efficacy of MSCs-based therapies. Cell variability within and between samples due to isolation and culture methods, along with the influence of the age, the genetic background, and the general health state of the donors are great challenges to standardize protocols and, consequently, contribute to the differences in the clinical outcomes between patients (Ankrum \& Karp, 2010; De Luca et al., 2019; Galipeau \& Sensébé, 2018; Hoogduijn \& Lombardo, 2019; Lukomska et al., 2019; Sipp et al., 2018). Even though, the number of registered clinical trials for MSCs are amazingly high. A search on public databases in September 2019 using the terms "MSC" or "mesenchymal stem cell" or "mesenchymal stromal cell" revealed 110 studies registered in the European Union Clinical Trials (2020) until 2018; 970 studies, including 19 conducted in Brazil, registered in the U.S. National Library of Medicine (2020); and 1040 registered since 2004 in the International Clinical Trials Registry Platform (ICTRP) of the World Health Organization (2020). Most of these clinical trials were still in phase I or II, as observed previously (Mastrolia et al., 2019), and less than 10\% of MSCs-based clinical trials were concluded with published results (Figure 4), which

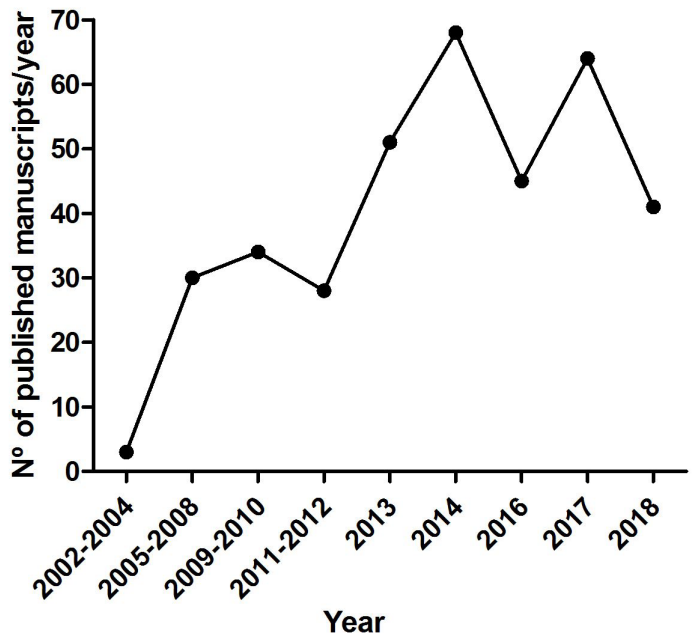

Figure 4. Number of scientific manuscripts on MSC-based clinical trials published over time. Timeline of published scientific articles about registered clinical trials using MSCs. The research was done in PubMed database using the terms "mesenchymal stem cell" OR "mesenchymal stromal cell" and selecting "clinical trials" as article type. 
is worrisome. Therefore, concerns for the clinical application of MSCs-based products should be also considered for veterinary regenerative medicine (Devireddy et al., 2017; Pinheiro et al., 2019; Uder et al., 2018), an expanding area of clinical research.

\section{Conclusion}

Mesenchymal stem/stromal cells (MSCs) - based products for regenerative medicine are widely used worldwide. However, outcomes from clinical trials have frustrated expectations and, consequently, led to the publication of guidelines for appropriate clinical conduct. MSCs were characterized in vitro and their in vivo identity is still debatable. Furthermore, the in vivo function of MSCs derived from distinct tissues are largely unknown, as well as the impact of cell variability related to differences between individuals, clinical conditions, and in vitro expansion on the result of cell therapy procedures. Therefore, caution should be taken when designing MSC-based therapeutic strategies.

\section{References}

Abbas, O. L., Özatik, O., Gönen, Z. B., Öğüt, S., Özatik, F. Y., Salkın, H., \& Musmul, A. (2006). Comparative analysis of mesenchymal stem cells from bone marrow, adipose tissue, and dental pulp as sources of cell therapy for zone of stasis burns. Journal of Investigative Surgery, 14, 1-14. http://dx.doi.org/10.1080/08941939.2018.1 433254. PMid:29442525.

Alimandi, M., Pierelli, L., Pino, V., Gentileschi, S., \& Sacchetti, B. (2019). The potential role of quorum sensing in clonal growth and subsequent expansion of bone marrow stromal cell strains in culture. Stem Cells International, 2019, 1579102. http://dx.doi.org/10.1155/2019/1579102. PMid:31467557.

Andrzejewska, A., Lukomska, B., \& Janowski, M. (2019). Concise review: mesenchymal stem cells: from roots to boost. Stem Cells, 37(7), 855-864. http://dx.doi.org/10.1002/stem.3016. PMid:30977255.

Ankrum, J., \& Karp, J. M. (2010). Mesenchymal stem cell therapy: two steps forward, one step back. Trends in Molecular Medicine, 16(5), 203-209. http://dx.doi.org/10.1016/j.molmed.2010.02.005. PMid:20335067.

Armulik, A., Genové, G., \& Betsholtz, C. (2011). Pericytes: Developmental, physiological, and pathological perspectives, problems, and promises. Developmental Cell, 21(2), 193-215. http://dx.doi.org/10.1016/j. devcel.2011.07.001. PMid:21839917.

Bari, C., Dell'Accio, F., Tylzanowski, P., \& Luyten, F. P. (2001). Multipotent mesenchymal stem cells from adult human synovial membrane. Arthritis \& Rheumatology, 44(8), 1928-1942. http://dx.doi.org/10.1002/15290131(200108)44:8<1928::AID-ART331>3.0.CO;2-P. PMid:11508446.

Berger, A. C., Beachy, S. H., \& Olson, S. (2014). Stem cell therapies: opportunities for ensuring the quality and safety of clinical offerings. Washington: National Academies Press. http://dx.doi.org/10.17226/18746.

Bianco, P. (2014). "Mesenchymal" stem cells. Annual Review of Cell and Developmental Biology, 30(1), 677-704. http://dx.doi.org/10.1146/annurev-cellbio-100913-013132. PMid:25150008.

Bianco, P. (2015). Stem cells and bone: a historical perspective. Bone, 70, 2-9. http://dx.doi.org/10.1016/j. bone.2014.08.011. PMid:25171959.

Bianco, P., \& Cossu, G. (1999). Uno, nessuno, centomila: searching for the identity of mesodermal progenitors. Experimental Cell Research, 251(2), 257-263. http://dx.doi.org/10.1006/excr.1999.4592. PMid:10471311.

Bianco, P., \& Robey, G. P. (2015). Skeletal stem cells. Development, 142(6), 1023-1027. http://dx.doi.org/10.1242/ dev.102210. PMid:25758217.

Bianco, P., Cao, X., Frenette, P. S., Mao, J. J., Robey, P. G., Simmons, P. J., \& Wang, C. Y. (2013). The meaning, the sense and the significance: translating the science of mesenchymal stem cells into medicine. Nature Medicine, 19(1), 35-42. http://dx.doi.org/10.1038/nm.3028. PMid:23296015.

Billaud, M., Donnenberg, V. S., Ellis, B. W., Meyer, E. M., Donnenberg, A. D., Hill, J. C., Richards, T. D., Gleason, T. G., \& Phillippi, J. A. (2017). Classification and functional characterization of vasa vasorum-associated perivascular progenitor cells in human aorta. Stem Cell Reports, 9(1), 292-303. http://dx.doi.org/10.1016/j. stemcr.2017.04.028. PMid:28552602.

Birbrair, A. (2018). Pericyte biology: Development, homeostasis, and disease. Advances in Experimental Medicine and Biology, 1109, 1-3. http://dx.doi.org/10.1007/978-3-030-02601-1_1. PMid:30523585.

Birbrair, A., Zhang, T., Wang, Z. M., Messi, M. L., Mintz, A., \& Delbono, O. (2015). Pericytes at the intersection between tissue regeneration and pathology. Clinical Science, 128(2), 81-93. http://dx.doi.org/10.1042/CS20140278. PMid:25236972.

Bonfanti, P., Barrandon, Y., \& Cossu, G. (2012). 'Hearts and bones': the ups and downs of 'plasticity' in stem cell biology.EMBOMolecular Medicine, 4(5), 353-361. http://dx.doi.org/10.1002/emmm.201200220. PMid:22383126.

Camargo, F. D., Chambers, S. M., \& Goodell, M. A. (2004). Stem cell plasticity: from transdifferentiation to macrophage fusion. Cell Proliferation, 37(1), 55-65. http://dx.doi.org/10.1111/j.1365-2184.2004.00300.x. PMid:14871237. 
Campagnoli, C., Roberts, I. A., Kumar, S., Bennett, P. R., Bellantuono, I., \& Fisk, N. M. (2001). Identification of mesenchymal stem/progenitor cells in human first-trimester fetal blood, liver, and bone marrow. Blood, 98(8), 2396-2402. http://dx.doi.org/10.1182/blood.V98.8.2396. PMid:11588036.

Caplan, A. I. (1991). Mesenchymal stem cells. Journal of Orthopaedic Research, 9(5), 641-650. http://dx.doi. org/10.1002/jor.1100090504. PMid:1870029.

Caplan, A. I. (2008). All MSCs are pericytes? Cell Stem Cell,3(3), 229-230. http://dx.doi.org/10.1016/j.stem.2008.08.008. PMid:18786406.

Caplan, A. I. (2010). What's in a name? Tissue Engineering. Part A, 16(8), 2415-2417. http://dx.doi.org/10.1089/ten. tea.2010.0216. PMid:20412005.

Castelo-Branco, M. T., Soares, I. D., Lopes, D. V., Buongusto, F., Martinusso, C. A., Rosario Junior, A., Souza, S. A., Gutfilen, B., Fonseca, L. M., Elia, C., Madi, K., Schanaider, A., Rossi, M. I., \& Souza, H. S. (2012). Intraperitoneal but not intravenous cryopreserved mesenchymal stromal cells home to the inflamed colon and ameliorate experimental colitis. PLoS One, 7(3), e33360. http://dx.doi.org/10.1371/journal.pone.0033360. PMid:22432015.

Castro-Malaspina, H., Gay, R. E., Resnick, G., Kapoor, N., Meyers, P., Chiarieri, D., McKenzie, S., Broxmeyer, H. E., \& Moore, M. A. (1980). Characterization of human marrow fibroblast colony-forming cells (CFU-F) and their progeny. Blood, 56(2), 289-301. http://dx.doi.org/10.1182/blood.V56.2.289.289. PMid:6994839.

Chen, W. C., Park, T. S., Iain, R., Murray, I. R., Zimmerlin, L., Lazzari, L., Huard, J., \& Péault, B. (2013). Cellular kinetics of perivascular MSC precursors. Stem Cells International,2013, 983059. http://dx.doi.org/10.1155/2013/983059. PMid:24023546.

Chen, W. C., Péault, B., \& Huard, J. (2015). Regenerative translation of human blood-vessel-derived MSC precursors. Stem Cells International, 375187, 375187. http://dx.doi.org/10.1155/2015/375187. PMid:26273304.

Chijimatsu, R., Ikeya, M., Yasui, Y., Ikeda, Y., Ebina, K., Moriguchi, Y., Shimomura, K., Hart, D. A., Hideki, Y., \& Norimasa, N. (2017). Characterization of mesenchymal stem cell-like cells derived from human iPSCs via neural crest development and their application for osteochondral repair. Stem Cells International, 2017, 1960965. http://dx.doi.org/10.1155/2017/1960965. PMid:28607560.

Cho, K. A., Park, M., Kim, Y. H., Woo, S. Y., \& Ryu, K. H. (2017). RNA sequencing reveals a transcriptomic portrait of human mesenchymal stem cells from bone marrow, adipose tissue, and palatine tonsils. Scientific Reports, 7(1), 17114. http://dx.doi.org/10.1038/s41598-017-16788-2. PMid:29214990.

Clevers, H. (2015). What is an adult stem cell? Science, 350(6266), 1319-1320. http://dx.doi.org/10.1126/science. aad7016. PMid:26659043.

Corselli, M., Chen, C. W., Sun, B., Yap, S., Rubin, J. P., \& Péault, B. (2012). The tunica adventitia of human arteries and veins as a source of mesenchymal stem cells. Stem Cells and Development, 21(8), 1299-1308. http://dx.doi. org/10.1089/scd.2011.0200. PMid:21861688.

Cretoiu, D., Radu, B. M., Banciu, A., Banciu, D. D., \& Cretoiu, S. M. (2017). Telocytes heterogeneity: From cellular morphology to functional evidence. Seminars in Cell \& Developmental Biology, 64, 26-39. http://dx.doi. org/10.1016/j.semcdb.2016.08.023. PMid:27569187.

Crisan, M., Yap, S., Casteilla, L., Chen, C. W., Corselli, M., Park, T. S., Andriolo, G., Sun, B., Zheng, B., Zhang, L., Norotte, C., Teng, P. N., Traas, J., Schugar, R., Deasy, B. M., Badylak, S., Buhring, H. J., Giacobino, J. P., Lazzari, L., Huard, J., \& Péault, B. (2008). A perivascular origin for mesenchymal stem cells in multiple human organs. Cell Stem Cell, 3(3), 301-313. http://dx.doi.org/10.1016/j.stem.2008.07.003. PMid:18786417.

De Luca, M., Aiuti, A., Cossu, G., Parmar, M., Pellegrini, G., \& Robey, P. G. (2019). Advances in stem cell research and therapeutic development. Nature Cell Biology, 21(7), 801-811. http://dx.doi.org/10.1038/s41556-019-0344-z. PMid:31209293.

Dellavalle, A., Sampaolesi, M., Tonlorenzi, R., Tagliafico, E., Sacchetti, B., Perani, L., Innocenzi, A., Galvez, B. G., Messina, G., Morosetti, R., Li, S., Belicchi, M., Peretti, G., Chamberlain, J. S., Wright, W. E., Torrente, Y., Ferrari, S., Bianco, P., \& Cossu, G. (2007). Pericytes of human skeletal muscle are myogenic precursors distinct from satellite cells. Nature Cell Biology, 9(3), 255-267. http://dx.doi.org/10.1038/ncb1542. PMid:17293855.

Devireddy, L. R., Boxer, L., Myers, M. J., Skasko, M., \& Screven, R. (2017). Questions and challenges in the development of mesenchymal stromal/stem cell-based therapies in veterinary medicine. Tissue Engineering. Part B, Reviews, 23(5), 462-470. http://dx.doi.org/10.1089/ten.teb.2016.0451. PMid:28142381.

Dias, R. B., Guimarães, J. A. M., Cury, M. B., Rocha, L. R., da Costa, E. S., Nogueira, L. P., Hochman-Mendez, C., Fortuna-Costa, A., Silva, A. K. F., Cunha, K. S., de Souza, S. A. L., Duarte, M. E. L., Sartore, R. C., \& Bonfim, D. C. (2019). The manufacture of gmp-grade bone marrow stromal cells with validated in vivo bone-forming potential in an orthopedic clinical center in Brazil. Stem Cells International, 2019, 2608482. http://dx.doi. org/10.1155/2019/2608482. PMid:31781235.

Díaz-Flores, L., Gutiérrez, R., García, M. P., Sáez, F. J., Díaz-Flores Junior, L., Valladares, F., \& Madrid, J. F. (2014). CD34+ stromal cells/fibroblasts/fibrocytes/telocytes as a tissue reserve and a principal source of mesenchymal cells. Location, morphology, function and role in pathology. Histology and Histopathology, 29(7), 831-870. http://dx.doi.org/10.14670/HH-29.831. PMid:24488810.

Díaz-Flores, L., Gutiérrez, R., Madrid, J. F., Varela, H., Valladares, F., Acosta, E., Martín-Vasallo, P., \& Díaz-Flores, L. Jr (2009). Pericytes. Morphofunction, interactions and pathology in a quiescent and activated mesenchymal cell niche. Histology and Histopathology, 24(7), 909-969. http://dx.doi.org/10.14670/HH-24.909. PMid:19475537. 
Dominici, M., Le Blanc, K., Mueller, I., Slaper-Cortenbach, I., Marini, F., Krause, D., Deans, R., Keating, A., Prockop, D. J., \& Horwitz, E. (2006). Minimal criteria for defining multipotent mesenchymal stromal cells. The International Society for Cellular Therapy position statement. Cytotherapy, 8(4), 315-317. http://dx.doi. org/10.1080/14653240600855905. PMid:16923606.

Dominici, M., Nichols, K., Srivastava, A., Weiss, D. J., Eldridge, P., Cuende, N., Deans, R. J., Rasko, J. E., Levine, A. D., Turner, L., Griffin, D. L., O'Donnell, L., Forte, M., Mason, C., Wagena, E., Janssen, W., Nordon, R., Wall, D., Ho, H. N., Ruiz, M. A., Wilton, S., Horwitz, E. M., \& Gunter, K. C. (2015). Positioning a scientific community on unproven cellular therapies: the 2015 International Society for Cellular Therapy perspective. Cytotherapy, 17(12), 1663-1666. http://dx.doi.org/10.1016/j.jcyt.2015.10.007. PMid:26589750.

Dupin, E., Calloni, G. W., Coelho-Aguiar, J. M., \& Le Douarin, N. M. (2018). The issue of the multipotency of the neural crest cells. Developmental Biology, 444(Suppl.1), S47-S59. http://dx.doi.org/10.1016/j.ydbio.2018.03.024. PMid:29614271.

Engler, A. J., Sen, S., Sweeney, H. L., \& Discher, D. E. (2006). Matrix elasticity directs stem cell lineage specification. Cell, 126(4), 677-689. http://dx.doi.org/10.1016/j.cell.2006.06.044. PMid:16923388.

Erices, A., Conget, P., \& Minguell, J. J. (2000). Mesenchymal progenitor cells in human umbilical cord blood. British Journal of Haematology, 109(1), 235-242. http://dx.doi.org/10.1046/j.1365-2141.2000.01986.x. PMid:10848804.

Eto, S., Goto, M., Soga, M., Kaneko, Y., Uehara, Y., Mizuta, H., \& Era, T. (2018). Mesenchymal stem cells derived from human iPS cells via mesoderm and neuroepithelium have different features and therapeutic potentials. PLoS One, 13(7), e0200790. http://dx.doi.org/10.1371/journal.pone.0200790. PMid:30044827.

European Union Clinical Trials. (2020). Retrieved in 2020, May 1, from www.clinicaltrialsregister.eu

Feng J., Mantesso A., De Bari C., Nishiyama A., Sharpe P.T. (2011). Dual origin of mesenchymal stem cells contributing to organ growth and repair. Proceedings of the National Academy of Science U.S.A., 108: 65036508. Doi:10.1073/pnas.1015449108

Ferraro, F., Celso, C. L., \& Scadden, D. (2010). Adult stem cells and their niche. Advances in Experimental Medicine and Biology, 695, 155-168. http://dx.doi.org/10.1007/978-1-4419-7037-4_11. PMid:21222205.

Ferreira, M. L., Silva, P. C., Alvarez Silva, L. H., Bonfim, D. C., Conilho Macedo Müller, L. C., Espósito, C. C., \& Schanaider, A. (2012). Heterologous mesenchymal stem cells successfully treat femoral pseudarthrosis in rats. Journal of Translational Medicine, 10(1), 51. http://dx.doi.org/10.1186/1479-5876-10-51. PMid:22429995.

Fitzsimmons, R. E. B., Mazurek, M. S., Soos, A., \& Simmons, C. A. (2018). Mesenchymal stromal/stem cells in regenerative medicine and tissue engineering. Stem Cells International, 2018, 8031718. http://dx.doi. org/10.1155/2018/8031718. PMid:30210552.

Fortier, L. A., \& Travis, A. J. (2011). Stem cells in veterinary medicine. Stem Cell Research \& Therapy, 2(1), 9. http:// dx.doi.org/10.1186/scrt50. PMid:21371354.

Freeman, B. T., Jung, J. P., \& Ogle, B. M. (2015). Single-cell RNA-Seq of bone marrow-derived mesenchymal stem cells reveals unique profiles of lineage priming. PLoS One, 10(9), e0136199. http://dx.doi.org/10.1371/journal. pone.0136199. PMid:26352588.

French, K. C., Antonyak, M. A., \& Cerione, R. A. (2017). Extracellular vesicle docking at the cellular port: extracellular vesicle binding and uptake. Seminars in Cell \& Developmental Biology, 67, 48-55. http://dx.doi.org/10.1016/j. semcdb.2017.01.002. PMid:28104520.

Friedenstein, A. J., Piatetzky-Shapiro, I. I., \& Petrakova, K. V. (1966). Osteogenesis in transplants of bone marrow cells. Journal of Embryology and Experimental Morphology, 16(3), 381-390. PMid:5336210.

Fung, M., Yuan, Y., Atkins, H., Shi, Q., \& Bubela, T. (2017). Responsible translation of stem cell research: an assessment of clinical trial registration and publications. Stem Cell Reports, 8(5), 1190-1201. http://dx.doi. org/10.1016/j.stemcr.2017.03.013. PMid:28416287.

Galipeau, J., \& Sensébé, L. (2018). Mesenchymal stromal cells: clinical challenges and therapeutic opportunities. Cell Stem Cell, 22(6), 824-833. http://dx.doi.org/10.1016/j.stem.2018.05.004. PMid:29859173.

Gimona, M., Pachler, K., Laner-Plamberger, S., Schallmoser, K., \& Rohde, E. (2017). Manufacturing of human extracellular vesicle-based therapeutics for clinical use. International Journal of Molecular Sciences, 18(6), el190. http://dx.doi.org/10.3390/ijms18061190. PMid:28587212.

Göritz, C., Dias, D. O., Tomilin, N., Barbacid, M., Shupliakov, O., \& Frisén, J. (2011). A pericyte origin of spinal cord scar tissue. Science, 333(6039), 238-242. http://dx.doi.org/10.1126/science.1203165. PMid:21737741.

Gronthos, S., Mankani, M., Brahim, J., Robey, P. G., \& Shi, S. (2000). Postnatal human dental pulp stem cells (DPSCs) in vitro and in vivo. Proceedings of the National Academy of Sciences of the United States of America, 97(25), 13625-13630. http://dx.doi.org/10.1073/pnas.240309797. PMid:11087820.

Guimarães-Camboa, N., Cattaneo, P., Sun, Y., Moore-Morris, T., Gu, Y., Dalton, N. D., Rockenstein, E., Masliah, E., Peterson, K. L., Stallcup, W. B., Chen, J., \& Evans, S. M. (2017). Pericytes of multiple organs do not behave as mesenchymal stem cells in vivo. Cell Stem Cell, 20(3), 345-359. http://dx.doi.org/10.1016/j.stem.2016.12.006. PMid:28111199.

Guiu, J., Hannezo, E., Yui, S., Demharter, S., Ulyanchenko, S., Maimets, M., Jørgensen, A., Perlman, S., Lundvall, L., Mamsen, L. S., Larsen, A., Olesen, R. H., Andersen, C. Y., Thuesen, L. L., Hare, K. J., Pers, T. H., Khodosevich, K., Simons, B. D., \& Jensen, K. B. (2019). Tracing the origin of adult intestinal stem cells. Nature, 570(7759), 107-111. http://dx.doi.org/10.1038/s41586-019-1212-5. PMid:31092921. 
Hay, E. D. (2005). The mesenchymal cell, its role in the embryo, and the remarkable signaling mechanisms that create it. Developmental Dynamics, 233(3), 706-720. http://dx.doi.org/10.1002/dvdy.20345. PMid:15937929.

Herzenberg, L. A., Parks, D., Sahaf, B., Perez, O., Roederer, M., \& Herzenberg, L. A. (2002). The history and future of the fluorescence activated cell sorter and flow cytometry: a view from Stanford. Clinical Chemistry, 48(10), 1819-1827. http://dx.doi.org/10.1093/clinchem/48.10.1819. PMid:12324512.

Ho, Y.-T., Shimbo, T., Wijaya, E., Ouchi, Y., Takaki, E., Yamamoto, R., Kikuchi, Y., Kaneda, Y., \& Tamai, K. (2018). Chromatin accessibility identifies diversity in mesenchymal stem cells from different tissue origins. Scientific Reports, 8(1), 17765. http://dx.doi.org/10.1038/s41598-018-36057-0. PMid:30531792.

Hoogduijn, M. J., \& Lombardo, E. (2019). Concise review: mesenchymal stromal cells anno 2019: Dawn of the therapeutic Era? Stem Cells Translational Medicine, 8(11), 1126-1134. http://dx.doi.org/10.1002/sctm.19-0073. PMid:31282113.

Horwitz, E. M., Le Blanc, K., Dominici, M., Mueller, I., Slaper-Cortenbach, I., Marini, F. C., Deans, R. J., Krause, D. S., \& Keating, A. (2005). Clarification of the nomenclature for MSC: the International Society for Cellular Therapy position statement. Cytotherapy, 7(5), 393-395. http://dx.doi.org/10.1080/14653240500319234. PMid:16236628.

Hoshino, A., Chiba, H., Nagai, K., Ishii, G., \& Ochiai, A. (2008). Human vascular adventitial fibroblasts contain mesenchymal stem/progenitor cells. Biochemical and Biophysical Research Communications, 368(2), 305-310. http://dx.doi.org/10.1016/j.bbrc.2008.01.090. PMid:18230345.

In't Anker, P. S., Scherjon, S. A., Kleijburg-van der Keur, C., Noort, W. A., Claas, F. H. J., Willemze, R., Fibbe, W. E., \& Kanhai, H. H. H. (2003). Amniotic fluid as a novel source of mesenchymal stem cells for therapeutic transplantation. Blood, 102(4), 1548-1549. http://dx.doi.org/10.1182/blood-2003-04-1291. PMid:12900350.

International Society for Stem Cell Research - ISSCR. (2006). Guidelines for the conduct of human embryonic stem cell research. Illinois: ISSCR.

International Society for Stem Cell Research - ISSCR. (2008). Guidelines on the clinical translation of stem cells. Illinois: ISSCR.

International Society for Stem Cell Research - ISSCR. (2016). Guidelines for stem cell research and clinical translation. Illinois: ISSCR.

Isern, J., García-García, A., Martín, A. M., Arranz, L., Martín-Pérez, D., Torroja, C., Sánchez-Cabo, F., \& Méndez-Ferrer, S. (2014). The neural crest is a source of mesenchymal stem cells with specialized hematopoietic stem cell niche function. eLife, 3, e03696. http://dx.doi.org/10.7554/eLife.03696. PMid:25255216.

Katsuda, T., \& Ochiya, T. (2015). Molecular signatures of mesenchymal stem cell-derived extracellular vesiclemediated tissue repair. Stem Cell Research \& Therapy, 6(1), 212. http://dx.doi.org/10.1186/s13287-015-0214-y. PMid:26560482.

Kern, S., Eichler, H., Stoeve, J., Klüter, H., \& Bieback, K. (2006). Comparative analysis of mesenchymal stem cells from bone marrow, umbilical cord blood, or adipose tissue. Stem Cells, 24(5), 1294-1301. http://dx.doi. org/10.1634/stemcells.2005-0342. PMid:16410387.

Klein, A. M., \& Simons, B. D. (2011). Universal patterns of stem cell fate in cycling adult tissues. Development, 138(15), 3103-3111. http://dx.doi.org/10.1242/dev.060103. PMid:21750026.

Kondo, A., \& Kaestner, K. H. (2019). Emerging diverse roles of telocytes. Development, 146(14), dev175018. http:// dx.doi.org/10.1242/dev.175018. PMid:31311805.

Konstantinov, I. E. (2000). In search of Alexander A. Maximow: the man behind the unitarian theory of hematopoiesis. Perspectives in Biology and Medicine, 43(2), 269-276. http://dx.doi.org/10.1353/pbm.2000.0006. PMid:10804590.

Krause, D. S., Theise, N. D., Collector, M. I., Henegariu, O., Hwang, S., Gardner, R., Neutzel, S., \& Sharkis, S. J. (2001). Multi-organ, multi-lineage engraftment by a single bone marrow-derived stem cell. Cell, 105(3), 369-377. http:// dx.doi.org/10.1016/S0092-8674(01)00328-2. PMid:11348593.

Kretzschmar, K., \& Watt, F. M. (2012). Lineage tracing. Cell,148(1-2), 33-45. http://dx.doi.org/10.1016/j.cell.2012.01.002. PMid:22265400.

Kuznetsov, S. A., Mankani, M. H., Gronthos, S., Satomura, K., Bianco, P., \& Robey, P. G. (2001). Circulating skeletal stem cells. The Journal of Cell Biology, 153(5), 1133-1140. http://dx.doi.org/10.1083/jcb.153.5.1133. PMid:11381097.

Lagasse, E., Shizuru, J. A., Uchida, N., Tsukamoto, A., \& Weissman, I. L. (2001). Toward regenerative medicina. Immunity, 14(4), 425-436. http://dx.doi.org/10.1016/S1074-7613(01)00123-6. PMid:11336688.

Latifkar, A., Hur, Y. H., Sanchez, J. C., Cerione, R. A., \& Antonyak, M. A. (2019). New insights into extracellular vesicle biogenesis and function. Journal of Cell Science, 132(13), jcs222406. http://dx.doi.org/10.1242/jcs.222406. PMid:31263077.

Lazarus, H. M., Haynesworth, S. E., Gerson, S. L., Rosenthal, N. S., \& Caplan, A. I. (1995). Ex vivo expansion and subsequent infusion of human bone marrow-derived stromal progenitor cells (mesenchymal progenitor cells): implications for therapeutic use. Bone Marrow Transplantation, 16(4), 557-564. PMid:8528172.

Le Blanc, K., Rasmusson, I., Sundberg, B., Götherström, C., Hassan, M., Uzunel, M., \& Ringdén, O. (2004). Treatment of severe acute graft-versus-host disease with third party haploidentical mesenchymal stem cells. Lancet, 363(9419), 1439-1441. http://dx.doi.org/10.1016/S0140-6736(04)16104-7. PMid:15121408. 
Li, S., Chen, L.-X., Peng, X.-H., Wang, C., Qin, B.-Y., Tan, D., Han, C.-X., Yang, H., Ren, X.-N., Liu, F., Xu, C.-H., \& Zhou, X.-H. (2018). Overview of the reporter genes and reporter mouse models. Animal Models and Experimental Medicine, 1(1), 29-35. http://dx.doi.org/10.1002/ame2.12008. PMid:30891544.

Lin, C. S., Xin, Z. C., Dai, J., \& Lue, T. F. (2013). Commonly used mesenchymal stem cell markers and tracking labels: limitations and challenges. Histology and Histopathology, 28(9), 1109-1116. http://dx.doi.org/10.14670/ HH-28.1109. PMid:23588700.

Liu, S., Castro, L. F., Jin, P., Civini, S., Ren, J., Reems, J. A., Cancelas, J., Nayak, R., Shaw, G., O’Brien, T., McKenna, D. H., Armant, M., Silberstein, L., Gee, A. P., Hei, D. J., Hematti, P., Kuznetsov, S. A., Robey, P. G., \& Stroncek, D. F. (2017). Manufacturing differences affect human bone marrow stromal cell characteristics and function: comparison of production methods and products from multiple centers. Scientific Reports, 7(1), 46731. http:// dx.doi.org/10.1038/srep46731. PMid:28447618.

Liu, S., Stroncek, D. F., Zhao, Y., Chen, V., Shi, R., Chen, J., Ren, J., Liu, H., Bae, H. J., Highfill, S. L., \& Jin, P. (2019). Single cell sequencing reveals gene expression signatures associated with bone marrow stromal cell subpopulations and time in culture. Journal of Translational Medicine, 17(1), 23. http://dx.doi.org/10.1186/ s12967-018-1766-2. PMid:30635013.

Lukomska, B., Stanaszek, L., Zuba-Surma, E., Legosz, P., Sarzynska, S., \& Drela, K. (2019). Challenges and controversies in human mesenchymal stem cell therapy. Stem Cells International, 2019, 9628536-10. http:// dx.doi.org/10.1155/2019/9628536. PMid:31093291.

Luria, E. A., Panasyuk, A. F., \& Friedenstein, A. Y. (1971). Fibroblast colony formation from monolayer cultures of blood cells. Transfusion, 11(6), 345-349. http://dx.doi.org/10.1111/j.1537-2995.1971.tb04426.x. PMid:5136066.

Lv, F. J., Tuan, R. S., Cheung, K. M., \& Leung, V. Y. (2014). Concise review: the surface markers and identity of human mesenchymal stem cells. Stem Cells, 32(6), 1408-1419. http://dx.doi.org/10.1002/stem.1681. PMid:24578244.

Mastrolia, I., Foppiani, E. M., Murgia, A., Candini, O., Samarelli, A. V., Grisendi, A., Veronesi, E., Horwitz, E. M., \& Dominici, M. (2019). Concise review: challenges in clinical development of mesenchymal stromal/stem cells. Stem Cells Translational Medicine, 8(11), 1135-1148. http://dx.doi.org/10.1002/sctm.19-0044. PMid:31313507.

McBeath, R., Pirone, D. M., Nelson, C. M., Bhadriraju, K., \& Chen, C. S. (2004). Cell shape, cytoskeletal tension, and RhoA regulate stem cell lineage commitment. Developmental Cell, 6(4), 483-495. http://dx.doi.org/10.1016/ S1534-5807(04)00075-9. PMid:15068789.

Menezes, K., Nascimento, M. A., Gonçalves, J. P., Cruz, A. S., Lopes, D. V., Curzio, B., Bonamino, M., de Menezes, J. R., Borojevic, R., Rossi, M. I., \& Coelho-Sampaio, T. (2014). Human mesenchymal cells from adipose tissue deposit laminin and promote regeneration of injured spinal cord in rats. PLoS One, 9(5), e96020. http://dx.doi. org/10.1371/journal.pone.0096020. PMid:24830794.

Mirowski, P., \& Van Horn, R. (2005). The contract research organization and the commercialization of scientific research. Social Studies of Science, 35(4), 503-548. http://dx.doi.org/10.1177/0306312705052103. PMid:16304738.

Morrison, S. J., \& Spradling, A. C. (2008). Stem cells and niches: mechanisms that promote stem cell maintenance throughout life. Cell,132(4), 598-611. http://dx.doi.org/10.1016/j.cell.2008.01.038. PMid:18295578.

Murray, I. R., \& Péault, B. (2015). Q\&A: Mesenchymal stem cells: where do they come from and is it important? BMC Biology, 13(1), 99. http://dx.doi.org/10.1186/s12915-015-0212-7. PMid:26596888.

Nagy, A. (2000). Cre recombinase: the universal reagent for genome tailoring. Genesis, 26(2), 99-109. http://dx.doi. org/10.1002/(SICI)1526-968X(200002)26:2<99::AID-GENE1>3.0.CO;2-B. PMid:10686599.

Owen, M. (1988). Marrow stromal stem cells. Journal of Cell Science, 1988(Suppl.10), 63-76. http://dx.doi.org/10.1242/ jcs.1988.Supplement_10.5. PMid:3077943.

Owen, M., \& Friedenstein, A. J. (1988). Stromal stem cells: marrow-derived osteogenic precursors. Ciba Foundation Symposium, 136, 42-60. PMid:3068016.

Packer, M. (2018). The Alchemist's nightmare: might mesenchymal stem cells that are recruited to repair the injured heart be transformed into fibroblasts rather than cardiomyocytes? Circulation, 137(19), 2068-2073. http://dx.doi.org/10.1161/CIRCULATIONAHA.117.032190. PMid:29735591.

Phinney, D. G., \& Pittenger, M. F. (2017). Concise review: MSC-derived exosomes for cell-free therapy. Stem Cells, 35(4), 851-858. http://dx.doi.org/10.1002/stem.2575. PMid:28294454.

Pinheiro, L. L., Lima, A. R., \& Branco, E. (2019). Is stem cell commerce in small animal therapies scientifically and morally justified? Stem Cell Reviews and Reports, 15(4), 506-518. http://dx.doi.org/10.1007/s12015-01909898-z. PMid:31140074.

Pittenger, M. F., MacKay, A. M., Beck, S. C., Jaiswal, R. K., Douglas, R., Mosca, J. D., Moorman, M. A., Simonetti, D. W., Craig, S., \& Marshak, D. R. (1999). Multilineage potential of adult human mesenchymal stem cells. Science, 284(5411), 143-147. http://dx.doi.org/10.1126/science.284.5411.143. PMid:10102814.

Post, Y., \& Clevers, H. (2019). Defining adult stem cell function at its simplest: the ability to replace lost cells through mitosis. Cell Stem Cell, 25(2), 174-183. http://dx.doi.org/10.1016/j.stem.2019.07.002. PMid:31374197.

Prazeres, P. H. D. M., Sena, I. F. G., Borges, I. D. T., Azevedo, P. O., Andreotti, J. P., Paiva, A. E., Almeida, V. M., Guerra, D. A. P., Santos, G. S. P., Mintz, A., Delbono, O., \& Birbrair, A. (2017). Pericytes are heterogeneous in their origin within the same tissue. Developmental Biology, 427(1), 6-11. http://dx.doi.org/10.1016/j.ydbio.2017.05.001. PMid:28479340. 
Prockop, D. J., \& Youn Oh, J. (2012). Mesenchymal stem/stromal cells (MSCs): role as guardians of inflammation. Molecular Therapy, 20(1), 14-20. http://dx.doi.org/10.1038/mt.2011.211. PMid:22008910.

Quesenberry, P., \& Goldberg, L. (2017). A revisionist history of adult marrow stem cell biology or 'they forgot about the discard'. Leukemia, 31(8), 1678-1685. http://dx.doi.org/10.1038/leu.2017.155. PMid:28529310.

Quirici, N., Soligo, D., Bossolasco, P., Servida, F., Lumini, C., \& Deliliers, G. L. (2002). Isolation of bone marrow mesenchymal stem cells by anti-nerve growth factor receptor antibodies. Experimental Hematology, 30(7), 783-791. http://dx.doi.org/10.1016/S0301-472x(02)00812-3. PMid:12135677.

Ramalho-Santos, M., \& Willenbring, H. (2007). On the origin of the term "stem cell". Cell Stem Cell, 1(1), 35-38. http://dx.doi.org/10.1016/j.stem.2007.05.013. PMid:18371332.

Robey, P. (2017). "Mesenchymal stem cells": fact or fiction, and implications in their therapeutic use. F1000 Research, 6, 524. http://dx.doi.org/10.12688/f1000research.10955.1. PMid:28491279.

Roson-Burgo, B., Sanchez-Guijo, F., Del Cañizo, C., \& De Las Rivas, J. (2016). Insights into the human mesenchymal stromal/stem cell identity through integrative transcriptomic profiling. BMC Genomics, 17(1), 944. http://dx.doi. org/10.1186/s12864-016-3230-0. PMid:27871224.

Rozemüller, H., Prins, H. J., Naaijkens, B., Staal, J., Bühring, H. J., \& Martens, A. C. (2010). Prospective isolation of mesenchymal stem cells from multiple mammalian species using cross-reacting anti-human monoclonal antibodies. Stem Cells and Development,19(12), 1911-1921. http://dx.doi.org/10.1089/scd.2009.0510. PMid:20367498.

Sacchetti, B., Funari, A., Michienzi, S., Di Cesare, S., Piersanti, S., Saggio, I., Tagliafico, E., Ferrari, S., Robey, P. G., Riminucci, M., \& Bianco, P. (2007). Self-renewing osteoprogenitors in bone marrow sinusoids can organize a hematopoietic microenvironment. Cell,131(2), 324-336. http://dx.doi.org/10.1016/j.cell.2007.08.025. PMid:17956733.

Sacchetti, B., Funari, A., Remoli, C., Giannicola, G., Kogler, G., Liedtke, S., Cossu, G., Serafini, M., Sampaolesi, M. Tagliafico, E., Tenedini, E., Saggio, I., Robey, P. G., Riminucci, M., \& Bianco, P. (2016). No identical “Mesenchymal Stem Cells" at different times and sites: human committed progenitors of distinct origin and differentiation potential are incorporated as adventitial cells in microvessels. Stem Cell Reports, 6(6), 897-913. http://dx.doi. org/10.1016/j.stemcr.2016.05.011. PMid:27304917.

Schofield, R. (1978). The relationship between the spleen colony-forming cell and the haematopoietic stem cell. Blood Cells, 4(1-2), 7-25. PMid:747780.

Silva Meirelles, L., Caplan, A. I., \& Nardi, N. B. (2008). In search of the in vivo identity of mesenchymal stem cells. Stem Cells, 26(9), 2287-2299. http://dx.doi.org/10.1634/stemcells.2007-1122. PMid:18566331.

Silva Meirelles, L., Chagastelles, P. C., \& Nardi, N. B. (2006). Mesenchymal stem cells reside in virtually all post-natal organs and tissues. Journal of Cell Science, 119(11), 2204-2213. http://dx.doi.org/10.1242/ics.02932. PMid:16684817.

Silva Meirelles, L., Fontes, A. M., Covas, D. T., \& Caplan, A. I. (2009). Mechanisms involved in the therapeutic properties of mesenchymal stem cells. Cytokine \& Growth Factor Reviews, 20(5-6), 419-427. http://dx.doi. org/10.1016/j.cytogfr.2009.10.002. PMid:19926330.

Simmons, P. J., \& Torok-Storb, B. (1991). Identification of stromal cell precursors in human bone marrow by a novel monoclonal antibody, STRO-1. Blood, 78(1), 55-62. http://dx.doi.org/10.1182/blood.V78.1.55.55. PMid:2070060.

Sipp, D., Robey, P. G., \& Turner, L. (2018). Clear up this stem-cell mess. Nature, 561(7724), 455-457. http://dx.doi. org/10.1038/d41586-018-06756-9. PMid:30258150.

Slack, J. M. W. (2018). What is a stem cell? WIREs Developmental Biology, 7(5), e323. http://dx.doi.org/10.1002/ wdev.323. PMid:29762894.

Spangrude, G. J., Heimfeld, S., \& Weissman, I. L. (1988). Purification and characterization of mouse hematopoietic stem cells. Science, 241(4861), 58-62. http://dx.doi.org/10.1126/science.2898810. PMid:2898810.

Spees, J. L., Lee, R. H., \& Gregory, C. A. (2016). Mechanisms of mesenchymal stem/stromalcell function. Stem Cell Research \& Therapy, 7(1), 125. http://dx.doi.org/10.1186/s13287-016-0363-7. PMid:27581859.

Sutherland, H. J., Eaves, C. J., Eaves, A. C., Dragowska, W., \& Lansdorp, P. M. (1989). Characterization and partial purification of human marrow cells capable of initiating long-term hematopoiesis in vitro. Blood, 74(5), 15631570. http://dx.doi.org/10.1182/blood.V74.5.1563.1563. PMid:2790186.

Takashima, Y., Era, T., Nakao, K., Kondo, S., Kasuga, M., Smith, A. G., \& Nishikawa, S.-H. (2007). Neuroepithelial cells supply an initial transient wave of MSC differentiation. Cell,129(7), 1377-1388. http://dx.doi.org/10.1016/j. cell.2007.04.028. PMid:17604725.

Tang, W., Zeve, D., Suh, J. M., Bosnakovski, D., Kyba, M., Hammer, R. E., Tallquist, M. D., \& Graff, J. M. (2008). White fat progenitor cells reside in the adipose vasculature. Science, 322(5901), 583-586. http://dx.doi.org/10.1126/ science.1156232. PMid:18801968.

Tavassoli, M., \& Crosby, W. H. (1968). Transplantation of marrow to extramedullary sites. Science, 161(3836), 54-56. http://dx.doi.org/10.1126/science.161.3836.54. PMid:4871792.

Theise, N. D. (2010). Stem cell plasticity: Recapping the decade, mapping the future. Experimental Hematology, 38(7), 529-539. http://dx.doi.org/10.1016/j.exphem.2010.04.013. PMid:20438800.

Thomas, E. D., Lochte Junior, H. L., Lu, W. C., \& Ferrebee, J. W. (1957). Intravenous infusion of bone marrow in patients receiving radiation and chemotherapy. The New England Journal of Medicine, 257(11), 491-496. http:// dx.doi.org/10.1056/NEJM195709122571102. PMid:13464965. 
Till, J. E., \& McCulloch, E. A. (1961). A direct measurement of the radiation sensitivity of normal mouse bone marrow cells. Radiation Research, 14(2), 213-222. http://dx.doi.org/10.2307/3570892. PMid:13776896.

Tormin, A., Li, O., Brune, J. C., Walsh, S., Schütz, B., Ehinger, M., Ditzel, N., Kassem, M., \& Scheding, S. (2011). CD146 expression on primary nonhematopoietic bone marrow stem cells is correlated with in situ localization. Blood, 117(19), 5067-5077. http://dx.doi.org/10.1182/blood-2010-08-304287. PMid:21415267.

U.S. National Library of Medicine. (2020). Retrieved in 2020, May 1, from clinicaltrials.gov

Uder, C., Brückner, S., Winkler, S., Tautenhahn, H. M., \& Christ, B. (2018). Mammalian MSC from selected species: features and applications. Cytometry. Part A, 93(1), 32-49. http://dx.doi.org/10.1002/cyto.a.23239. PMid:28906582.

Vannucchi, M. G., \& Faussone-Pellegrini, M. S. (2016). The telocyte subtypes. Advances in Experimental Medicine and Biology, 913, 115-126. http://dx.doi.org/10.1007/978-981-10-1061-3_7. PMid:27796883.

Wagers, A. J., \& Weissman, I. L. (2004). Plasticity of adult stem cells. Cell,116(5), 639-648. http://dx.doi.org/10.1016/ S0092-8674(04)00208-9. PMid:15006347.

Wang, J., Jin, M., Ma, W. H., Zhu, Z., \& Wang, X. (2016). The history of telocyte discovery and understanding. Advances in Experimental Medicine and Biology, 913,1-21. http://dx.doi.org/10.1007/978-981-10-1061-3_1. PMid:27796877.

Weiss, A. R. R., \& Dahlke, M. H. (2019). Immunomodulation by mesenchymal stem cells (mscs): mechanisms of action of living, apoptotic, and dead MSCs. Frontiers in Immunology, 10, 1191. http://dx.doi.org/10.3389/ fimmu.2019.01191. PMid:31214172.

Williams, J. T., Southerland, S. S., Souza, J., Calcutt, A. F., \& Cartledge, R. G. (1999). Cells isolated from adult human skeletal muscle capable of differentiating into multiple mesodermal phenotypes. The American Surgeon, 65(1), 22-26. PMid:9915526.

Willis, G. R., Kourembanas, S., \& Mitsialis, S. A. (2017). Therapeutic applications of extracellular vesicles: perspectives from newborn medicine. Extracellular Vesicles, 1660, 409-432. http://dx.doi.org/10.1007/978-14939-7253-1_34. PMid:28828676.

World Health Organization - WHO. (2020). Retrieved in 2020, May 1, from www.who.int/ictrp/en

Yamazaki, T., \& Mukouyama, Y. S. (2018). Tissue specific origin, development, and pathological perspectives of pericytes. Frontiers in Cardiovascular Medicine, 5, 78. http://dx.doi.org/10.3389/fcvm.2018.00078. PMid:29998128.

Zheng, Y., Zhang, M., Qian, M., Wang, L., Cismasiu, V. B., Bai, C., Popescu, L. M., \& Wang, X. (2013). Genetic comparison of mouse lung telocytes with mesenchymal stem cells and fibroblasts. Journal of Cellular and Molecular Medicine, 17(4), 567-577. http://dx.doi.org/10.1111/jcmm.12052. PMid:23621815.

Zuk, P. A., Zhu, M., Mizuno, H., Huang, J., Futrell, W., Katz, A. J., Benhaim, P., Lorenz, P., \& Hedrick, M. H. (2001). Multilineage cells from human adipose tissue: implications for cell-based therapies. Tissue Engineering, 7(2), 211-228. http://dx.doi.org/10.1089/107632701300062859. PMid:11304456. 